\title{
Single nucleotide polymorphisms associated with non-contact soft tissue injuries in elite professional soccer players: influence on degree of injury and recovery time
}

Ricard Pruna ${ }^{1 \dagger}$, Rosa Artells ${ }^{2 \dagger}$, Jordi Ribas ${ }^{2,3}$, Bruno Montoro $^{4}$, Francesc Cos $^{5,6}$, Carme Muñoz $^{2}$, Gil Rodas ${ }^{1}$ and Nicola Maffulli ${ }^{7^{*}}$

\begin{abstract}
Background: The biological mechanisms involved in non-contact musculoskeletal soft tissue injuries (NCMSTI) are poorly understood. Genetic risk factors may be associated with susceptibility to injuries, and may exert marked influence on recovery times.

Methods: Data on type and degree of injury and recovery time were collected in 73 male professional soccer players (43 White, 11 Black Africans and 19 Hispanics) who suffered total of 242 injuries (203 muscle, 24 ligament, and 15 tendon injuries). One single nucleotide polymorphism (SNPs) in the following genes were analyzed: Elastin (ELN); Titin (TTN); SRY-related HMG-box (SOX15); Insulin-like growth factor 2 (IGF2); Chemokine, CC motif, ligand 2 (CCL2); Collagen type 1 alpha 1(COL1A1); Collagen type 5 alpha 1 (COL5A1), and Tenascin C (TNC).

Results: There was evidence of a statistically significant association between the degree of injury and the IGF2 genotype $(P=0.034)$. In addition, there was evidence of a statistically significant association between the degree of muscle injury and CCL2 ( $P=0.026)$ Finally, there was evidence of a statistically significant association between ELN and degree of injury $(p=0.009)$ and recovery time $(P=0.043)$. There was no evidence of a statistically significant association between any of the genes studied and degree of injury or recovery time for tendon injuries.
\end{abstract}

Conclusion: SNPs in the IGF2, CCL2, and ELN genes may be associated to the degree and recovery time of NCMSTI.

Keywords: Single nucleotide polymorphisms, Musculoskeletal soft tissue, IGF2, ELN, CCL2, COL5A1

\section{Background}

The interaction between extrinsic and intrinsic factors, including genetic risk factors, is crucial to assessing causation in non-contact soft musculoskeletal tissue injuries (NCSMTIs) [1-3]. Careful epidemiological studies are currently the main and most reliable source of objective knowledge on predisposition to injuries [4-8]. However, few well designed studies have investigated the aetiology of muscle, ligament and tendon injuries [9]. To

\footnotetext{
* Correspondence: n.maffulli@gmul.ac.uk

${ }^{\dagger}$ Equal contributors

${ }^{7}$ Centre for Sports and Exercise Medicine, Queen Mary University of London, Barts and The London School of Medicine and Dentistry, London, UK

Full list of author information is available at the end of the article
}

date, there is no conclusive scientific evidence to identify risk factors for NCSMTIs, or to explain interindividual differences in recovery times, although recent studies have identified genetic risk factors in the pathogenesis of NCSMTIs [2,10-13].

A single nucleotide polymorphism (SNP) is a DNA sequence variation which occurs when a single nucleotide in the genome or other shared sequence differs between members of a species or between paired chromosomes in a given individual. SNPs can occur throughout the genome, both in coding and non-coding regions, and can affect the response of an individual to a specific treatment or other stimuli. SNPs in genes related to the biology of muscles, $[14,15]$ tendons [16-18] and ligaments [19] have been associated with 
injury recovery time $[20,21]$. In addition, other genes have been related to tissue repair (elastin [ELN]) [22,23], muscle assembly and force transmission (titin [TTN]) [24], skeletal muscle regeneration (SRY-related HMG-box [SOX15]) [25], muscle damage (insulin-like growth factor 2 [IGF2]) [26], response to muscle damage (chemokine, $\mathrm{CC}$ motif, ligand 2 [CCL2]) [27], ligament ruptures ([COL1A1] and collagen type 5 alpha 1[COL5A1]) [28], and tendinopathy (COL5A1 and tenascin [TNC]) $[10,29]$.

The present study investigated the association of SNPs in these eight genes in a population of professional soccer players from an elite European soccer club to determine the potential relationship between these SNPs and degree of injury and recovery time.

\section{Methods}

The study was approved by the Ethics Committee of the Hospital Clinic, Barcelona (registry no. 2012/7117), and all players gave their signed informed consent.

\section{Population and types of injuries}

Data were collected on injuries suffered by 73 elite soccer players from Futbol Club Barcelona (Barcelona, Catalunya, Spain) over the course of three consecutive soccer seasons. All the players included in the study, either from the first $(\mathrm{n}=49)$ and the second team $(\mathrm{n}=26)$ lived within $30 \mathrm{~km}$ of the training field, and were thus subjected to the same climate and environmental conditions. All the players undertook similar amount of work, followed similar diet (data not available), and took the same ergogenic aids. The training field, the playing fields and the injury prevention protocols were also identical for all the players. The treatment protocol for each type of injury, including medication and physical therapy, was the same for all the players, and all treatment was supervised by the same medical team.

Given the high qualification level of the study population (73 male professional soccer players from the same football team) and based on the sample size $(n=242)$ of the NCSMTIs encountered, we decided to study the most common injury in each tissue group, i.e. hamstring injuries for muscle injuries, patellar tendon injuries for tendon injuries, and medial collateral ligament injuries for ligament injuries. Data on injuries were collected in accordance with the Union of European Football Associations (UEFA) protocol [30]. Ultrasound and magnetic resonance imaging scans were used to morphologically classify the injuries by anatomic region. Injuries were classified as mild, moderate or severe [31] according to the number of days that a player needed to be absent from training and/or competition [32,33]: mild, 1-15 days; moderate, 16-30 days; and severe, more than 30 days. A mild lesion presents minimal tissue damage (up to $25 \%$ ), a moderate injury involves $50 \%$ of the tissue and, finally, in a serious injury more than $50 \%$ of the tissue is involved. Recovery time was defined as the time from the date of injury until the date the player could return to full training or competition.

\section{DNA extraction and genotyping}

Approximately $4 \mathrm{~mL}$ of whole blood was collected from each subject into EDTA vacutainer tubes, and stored at $4^{\circ} \mathrm{C}$ until total DNA extraction. Genomic DNA from whole blood was isolated using QIAmp DNA Blood Minikit (Qiagen, Valencia, CA) following the manufacturer's instructions. To measure DNA quantity, a NanoDrop ND1000 Spectrophotometer (Thermo Fisher Scientific INC, Waltham, MA) was used. DNA was stored at $-20^{\circ} \mathrm{C}$ until analysed.

Table 1 shows the characteristics of all the SNPs analyzed. Primers and probes were obtained from Applied Biosystems (AB; Assays-on-Demand SNP genotyping product, Foster City, CA).

SNP analysis was performed using a real-time polymerase chain reaction (PCR) Allelic Discrimination TaqMan Assay $(\mathrm{AB})$ with minor modifications. All PCR reactions were run in duplicate, and contained 50 ng of each individual's DNA; $6.25 \mu \mathrm{L}$ TaqMan Universal Master Mix (AB); $0.25 \mu \mathrm{L}$ primers and probes $(\mathrm{AB})$ and water for a final volume of $12.5 \mu \mathrm{L}$. Real-time PCR was performed on an ABIPrism 7500 Sequence Detection System (AB) using the following conditions: $50^{\circ} \mathrm{C}$ for 2 minutes, $95^{\circ} \mathrm{C}$ for 10 minutes, and 40 cycles of amplification $\left(95^{\circ} \mathrm{C}\right.$ for 15 seconds and $60^{\circ} \mathrm{C}$ for 1 minute). For each cycle, the software determined the fluorescent signal from the VIC- or FAM- labeled probe.

\section{Statistical analyses}

Descriptive statistics of the main demographic variables of the studied population (mean, standard deviation, or median, range, for continuous data, and frequency tables for specific data) was calculated. Frequency tables were used for the distribution of the SNPs for the different genes evaluated.

Table 1 Characteristics and functions of the SNPs included in the study

\begin{tabular}{lll}
\hline Gene & Related function & rsNCBI \\
\hline ELN [22] & Tissue repair & rs2289360 \\
TTN [24] & Muscle assembly & rs2742327 \\
& Force transmission & \\
SOX15 [25] & Skeletal muscle regeneration & rs4227 \\
IGF2 [26] & Muscle damage & rs3213221 \\
CCL2 [27] & Response to muscle damage & rs2857656 \\
TNC [10] & Tendinopathy & rs2104772 \\
COL1A1 [28] & Ligament ruptures & rs1800012 \\
COL5A1 [28] & Ligament ruptures & rs12722 \\
& Tendinopathy & \\
\hline
\end{tabular}

The numbers in brackets are the relevant references. 
The association between type and degree of injury and the SNPs (in ELN, TTN, SOX15, IGF2, CCL2, COL1A1, COL5A1 and TNC) was determined with the Chi-square test and Fisher's exact test when necessary. The association between SNPs and injury recovery time was evaluated using multivariate analysis of variance. All statistical analyses were performed using SPSS version 14.0 for Windows (SPSS Inc., Chicago, IL). Significance was set at P $\leq$ 0.05. The Benjamini-Hochberg P-value corrective test for multiple comparisons was applied.

\section{Results}

\section{Study population}

Of the 73 soccer players included in the study, 43 (58.9\%) were White, 11 (15.1\%) were Black Africans, and $19(26 \%)$ were Hispanics. The median age for all players was 26.2 years (range, 19-35), median weight was 75.6 kilos (range, 64-92), median height was 1.79 meters (range, 1.66-1.95), and median work load was 16027 minutes per year (267 hours/season/player) (range, 15301-16544), with no significant differences between ethnic groups for any of these characteristics.

Over the course of the three seasons of the study, a total of 242 NCMSTIs were recorded for all 73 players. Two hundred and three were muscle injuries, of which 129 (63.5\%) were mild, 69 (34\%) moderate, and 5 (2.5\%) severe. Twenty-four were ligament injuries, of which 15 $(62.5 \%)$ were mild, 3 (12.5\%) moderate, and $6(25 \%)$ severe. Fifteen were tendon injuries, of which 7 (46.7\%) were mild, 7 (46.7\%) moderate, and 1 (6.6\%) severe.

Allele frequencies, degree of injury and recovery time Table 2 shows the allele frequencies of the eight genes, both for the present study and according to the NCBI

Table 2 Genotypic frequencies in the present study and for WHITE (HapMap CEU), Black African (HapMap YRI) and Hispanic (HISP1) populations in NCBI dbSNP

\begin{tabular}{|c|c|c|c|c|c|c|c|c|c|}
\hline \multirow[t]{4}{*}{ Gene } & \multirow[t]{4}{*}{ Genotype } & \multicolumn{7}{|l|}{ Population } & \multirow[t]{4}{*}{$p$-value } \\
\hline & & \multirow{3}{*}{$\begin{array}{l}\text { Total } \\
\text { Present study } \\
N=73\end{array}$} & \multicolumn{2}{|l|}{ White } & \multicolumn{2}{|l|}{ Black African } & \multicolumn{2}{|l|}{ Hispanic } & \\
\hline & & & Present study & HapMap & Present study & HapMap & Present study & HapMap & \\
\hline & & & $\mathrm{N}=43$ & CEU & $N=11$ & YRI & $N=19$ & HISP1 & \\
\hline \multirow[t]{3}{*}{ ELN } & $\mathrm{AA}$ & $27.40 \%$ & $14 \%$ & $15.50 \%$ & $45.45 \%$ & $40.20 \%$ & $47.40 \%$ & $\mathrm{n} / \mathrm{a}$ & $<0.0001$ \\
\hline & $A G$ & $56.20 \%$ & $65.10 \%$ & $65.11 \%$ & $36.40 \%$ & $44.20 \%$ & $47.40 \%$ & $\mathrm{n} / \mathrm{a}$ & \\
\hline & GG & $16.40 \%$ & $20.90 \%$ & $36.40 \%$ & $18.20 \%$ & $15.20 \%$ & $5.20 \%$ & $\mathrm{n} / \mathrm{a}$ & \\
\hline \multirow[t]{3}{*}{ TTN } & AA & $50.70 \%$ & $58.10 \%$ & $68.10 \%$ & $27.30 \%$ & $14.20 \%$ & $47.40 \%$ & $\mathrm{n} / \mathrm{a}$ & $<0.0001$ \\
\hline & $A G$ & $39.70 \%$ & $37.20 \%$ & $26.50 \%$ & $45.50 \%$ & $46.90 \%$ & $42.10 \%$ & $\mathrm{n} / \mathrm{a}$ & \\
\hline & GG & $9.60 \%$ & $4.70 \%$ & $5.30 \%$ & $27.30 \%$ & $38.90 \%$ & $10.50 \%$ & $\mathrm{n} / \mathrm{a}$ & \\
\hline \multirow[t]{3}{*}{ SOX15 } & $\pi$ & $58.90 \%$ & $62.80 \%$ & $58.40 \%$ & $36.40 \%$ & $20.40 \%$ & $63.20 \%$ & $52.20 \%$ & $<0.0001$ \\
\hline & TG & $31.50 \%$ & $32.60 \%$ & $33.60 \%$ & $36.40 \%$ & $49.60 \%$ & $26.30 \%$ & $34.80 \%$ & \\
\hline & GG & $9.60 \%$ & $4.70 \%$ & $8.00 \%$ & $27.30 \%$ & $30.10 \%$ & $10.50 \%$ & $13.00 \%$ & \\
\hline \multirow[t]{3}{*}{ IGF2 } & GG & $38.40 \%$ & $30.20 \%$ & $30.10 \%$ & $45.45 \%$ & $38.10 \%$ & $52.60 \%$ & $43.50 \%$ & $<0.0001$ \\
\hline & GC & $43.80 \%$ & $53.50 \%$ & $53.10 \%$ & $27.30 \%$ & $42.30 \%$ & $31.60 \%$ & $21.70 \%$ & \\
\hline & CC & $17.80 \%$ & $16.30 \%$ & $16.80 \%$ & $27.30 \%$ & $9.20 \%$ & $15.80 \%$ & $34.80 \%$ & \\
\hline \multirow[t]{3}{*}{ CCL2 } & GG & $43.80 \%$ & $39.50 \%$ & $65.20 \%$ & $54.50 \%$ & $52.20 \%$ & $47.40 \%$ & $\mathrm{n} / \mathrm{a}$ & $<0.0001$ \\
\hline & $\mathrm{GC}$ & $46.60 \%$ & $48.80 \%$ & $30.40 \%$ & $45.50 \%$ & $34.80 \%$ & $42.10 \%$ & $\mathrm{n} / \mathrm{a}$ & \\
\hline & CC & $9.60 \%$ & $11.60 \%$ & $4.03 \%$ & - & $13 \%$ & $10.50 \%$ & $\mathrm{n} / \mathrm{a}$ & \\
\hline \multirow[t]{3}{*}{ TNC } & AA & $35.60 \%$ & $30.20 \%$ & $31.70 \%$ & $45.45 \%$ & $46.70 \%$ & $42.10 \%$ & $\mathrm{n} / \mathrm{a}$ & $<0.0001$ \\
\hline & AT & $43.80 \%$ & $51.20 \%$ & $53.30 \%$ & $36.40 \%$ & $41.70 \%$ & $31.60 \%$ & $\mathrm{n} / \mathrm{a}$ & \\
\hline & $\pi$ & $20.50 \%$ & $18.60 \%$ & $15.00 \%$ & $18.20 \%$ & $11.70 \%$ & $26.30 \%$ & $\mathrm{n} / \mathrm{a}$ & \\
\hline \multirow[t]{3}{*}{ COL1A1 } & GG & $71.20 \%$ & $72.10 \%$ & - & $81.80 \%$ & $100 \%$ & $63.20 \%$ & $\mathrm{n} / \mathrm{a}$ & $<0.0001$ \\
\hline & GA & $26 \%$ & $23.30 \%$ & $100 \%$ & $18.20 \%$ & - & $36.80 \%$ & $\mathrm{n} / \mathrm{a}$ & \\
\hline & AA & $2.70 \%$ & $4.65 \%$ & - & - & - & - & $\mathrm{n} / \mathrm{a}$ & \\
\hline \multirow[t]{3}{*}{ COL5A1 } & $\pi$ & - & - & $24.50 \%$ & - & - & - & $\mathrm{n} / \mathrm{a}$ & $<0.0001$ \\
\hline & $\mathrm{TC}$ & $65.30 \%$ & $76.20 \%$ & $64.20 \%$ & $18.20 \%$ & $27.10 \%$ & $68.40 \%$ & $\mathrm{n} / \mathrm{a}$ & \\
\hline & CC & $34.70 \%$ & $23.80 \%$ & $11.30 \%$ & $81.80 \%$ & $72.90 \%$ & $31.60 \%$ & $\mathrm{n} / \mathrm{a}$ & \\
\hline
\end{tabular}

$\mathrm{P}$ value refer to the differences in genotypic frequencies between ethnic groups in the present study. $\mathrm{N} / \mathrm{A}$ : data not available. 
dbSNP. The frequency of the SNPs varied among the three sub-groups in the present study $(\mathrm{p}<0.0001)$.

Table 3 shows the association between SNPs and injured structure. SNPs in IGF2 and CCL2 were associated with the severity of muscle injuries. The 93 muscle injuries associated with the IGF2 GC genotype were significantly less severe than those associated with the IGF2 $\mathrm{CC}$ or GG genotypes $(\mathrm{p}=0.034)$ (Figure $1 \mathrm{~A}$, Table 3 ). The CCL2 genotypes CC and CG were also associated with less severe muscle injuries than the CCL2 GG genotype $(\mathrm{p}=0.026)$ (Figure $1 \mathrm{~B}$, Table 3$)$. Finally, the COL5A1 TC genotype showed a tendency towards an association with more severe muscle injuries $(p=0.08))$ (Figure 1C, Table 3).

The 10 ligament injuries associated with the ELN AA genotype were more severe than those associated with the ELN AG or GG genotypes $(\mathrm{p}=0.009)$ (Figure 2A, Table 3). SNPs in ELN also showed evidence of a statistically significant association with recovery time. Injuries associated with the ELN AG genotype required a shorter mean recovery time (24.7days) than those associated with the ELN GG (37.5 days) or AA (83.2 days) genotypes $(\mathrm{p}=0.043)$ (Figure $2 \mathrm{~B}$, Table 3$)$.

There was no evidence of a statistically significant association between the SNPs considered in the present study and tendon injuries (see Additional file 1).

\section{Discussion}

The prevention, diagnosis and management treatment of NCSMTIs are crucial in both professional and amateur sports [34]. NCSMTIs occur as a consequence of extrinsic and intrinsic factors. The extrinsic factors that may influence a soccer player's predisposition to injury are the design of the playing field, $[35,36]$ the characteristics of the ball, [36,37] air temperature, [36,38] altitude, $[36,39]$ and the time of the match $[36,40]$. The intrinsic factors that are considered risk factors for NCSMTIs are age, $[36,41,42]$ sex $[36,43,44]$ and prior injuries $[36,45]$. Despite rigorous controls over many extrinsic and intrinsic factors, a wide range of interindividual differences exists in number and degree of injuries and in recovery time, [46] suggesting that other factors, including genetic variations, [1-3] may exert an important influence on these differences.

The frequency of specific SNPs varies between different ethnic groups $[47,48]$. In the present study, we found significant differences in the frequency of all the SNPs among the three ethnic groups studied. Given these findings, it would be interesting to further investigate the relationship between ethnic differences and a player's predisposition to injury and recovery time.

In the present investigation, muscle injuries were the most frequent ailments $[5,49]$. The degree of muscle injury was related to SNPs in the IGF2 $(p=0.034)$ and CCL2 ( $\mathrm{p}=0.026)$ genes, but not with COL5A1 ( $\mathrm{p}=$ $0.08)$. Individuals with the IGF2 GC genotype experienced less severe injuries than those with the homozygous GG or CC genotypes (Table 3). Previous studies report that IGFs play a role in soft tissues growth, and increase their expression in response to degeneration and regeneration following an injury, when IGFs work with other genes, such as fibroblastic growth factor, interleukin $1 \beta$, interleukin 6 , and transforming growth factor- $\beta$, to influence satellite cell activation [50-52].

Individuals with the CCL2 GG genotype suffered more severe injuries than those with the $\mathrm{CC}$ or $\mathrm{CG}$ genotypes (Table 3). CCL2 is a small chemokine produced by both macrophages and satellite cells, [53] and plays key roles in inflammation and immunoregulation [27]. CCL2 expression increases dramatically following muscle damage, and recent data suggest that it plays significant roles in muscle damage, muscle repair and adaptation [15,27].

Table 3 Frequencies of genotypes related to degree of injury

\begin{tabular}{|c|c|c|c|c|c|c|c|}
\hline \multirow{2}{*}{$\begin{array}{l}\text { Injured } \\
\text { structure }\end{array}$} & \multirow[t]{2}{*}{ Gene } & \multirow[t]{2}{*}{ Genotype } & \multicolumn{3}{|l|}{ Degree } & \multirow{2}{*}{$\begin{array}{l}\text { Total } \\
\text { injuries }\end{array}$} & \multirow[t]{2}{*}{$p$ value } \\
\hline & & & Mild & Moderate & Severe & & \\
\hline \multirow[t]{8}{*}{ Muscle } & IGF2 & GG & $52(70.3 \%)$ & $19(25.7 \%)$ & $3(4.1 \%)$ & 203 & 0.034 \\
\hline & & GC & $54(58.1 \%)$ & 39 (41.9\%) & $0(0 \%)$ & & \\
\hline & & $\mathrm{CC}$ & $23(63.9 \%)$ & $11(30.6 \%)$ & $2(5.6 \%)$ & & \\
\hline & CCL2 & GG & $42(53.2 \%)$ & $34(43 \%)$ & $3(3.8 \%)$ & 203 & 0.026 \\
\hline & & GC/CC & $87(70.16 \%)$ & $35(28.22 \%)$ & $2(1.61 \%)$ & & \\
\hline & COL5A1 & $T \mathrm{~T}$ & - & - & - & 203 & 0.08 \\
\hline & & $\mathrm{TC}$ & $78(69 \%)$ & $31(27.4 \%)$ & $4(3.5 \%)$ & & \\
\hline & & $\mathrm{CC}$ & $47(56.6 \%)$ & $35(42.2 \%)$ & $1(1.2 \%)$ & & \\
\hline \multirow[t]{3}{*}{ Ligament } & ELN & AA & $5(50 \%)$ & 1 (10\%) & $4(40 \%)$ & 24 & 0.009 \\
\hline & & $A G$ & $10(83.3 \%)$ & $0(0 \%)$ & $2(16.7 \%)$ & & \\
\hline & & GG & $0(0 \%)$ & $2(100 \%)$ & $0(0 \%)$ & & \\
\hline
\end{tabular}



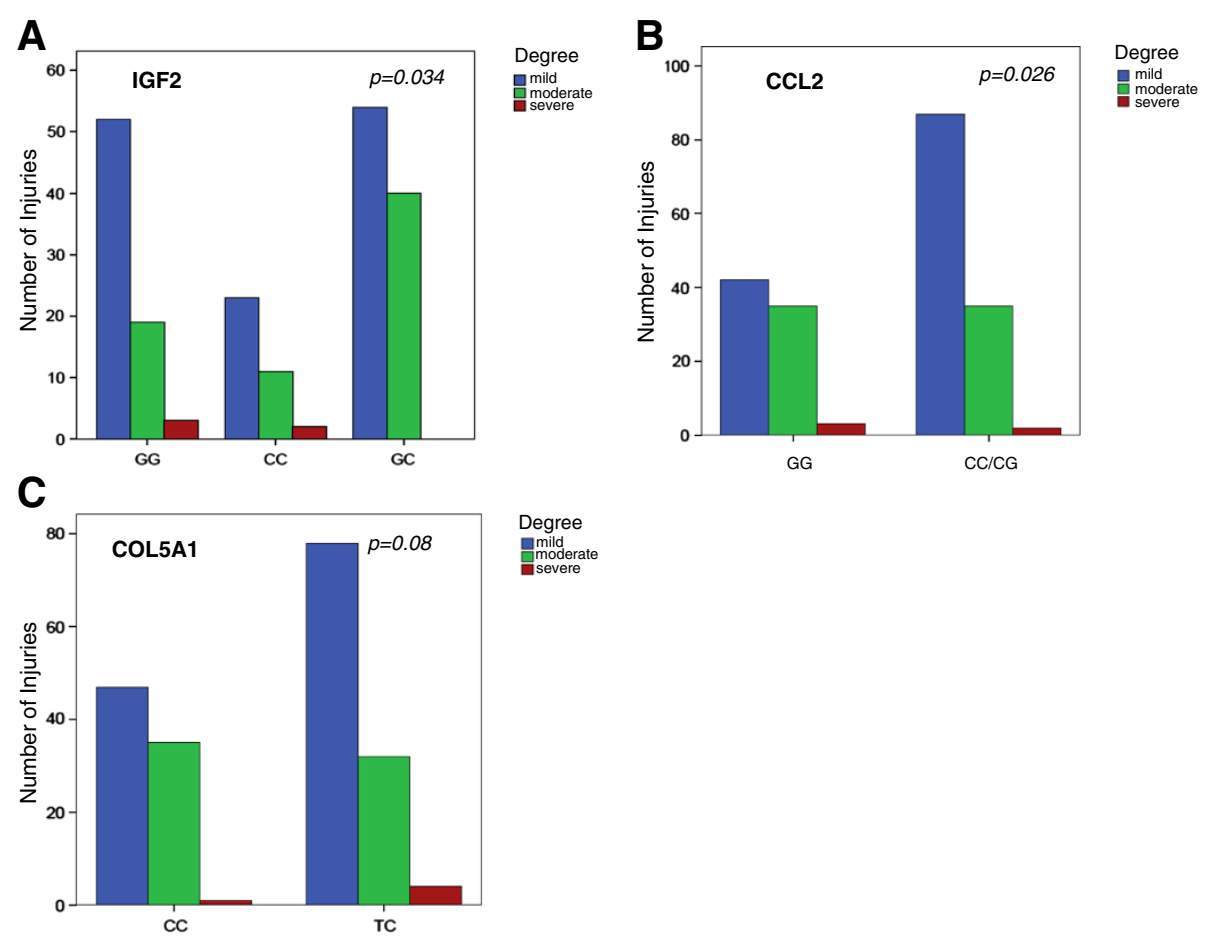

Figure 1 Relation between muscle injuries and degree. Association of IGF2, CCL2 and COL5A1 to degree of muscle injury. A) Individuals with the heterozygous variant of IGF2 suffered less severe injuries. B) Carriers of the CCL2 C allele experienced less severe injuries. C) Carriers of the COL5A1 T allele showed a tendency towards more severe injuries (see Table 3).

SNPs in CCL2 have been related to markers of muscle injury, such as creatine kinase and myoglobin levels and muscle pain [27].

Individuals with the COL5A1 CC genotype showed a tendency towards less severe muscle injuries than those with the TC genotype (Table 3). COL5A1 encodes the $\alpha 1$ chain of collagen type $\mathrm{V}$, which forms part of the extracellular matrix of the skeletal muscles [54]. These COL5A1 molecules connect with collagen type I fibers in noncartilage connective tissue, modulating fibrillogenesis. However, for this process to be successful, both $\mathrm{C}$ alleles must be present [55]. This is particularly evident in studies of tendinopathy, where the presence of the $\mathrm{C}$ allele has been associated with asymptomatic patients [12,56].

Although dealing with extremely high qualification athletes, we acknowledge that the size of our cohort is relatively small, and our results should be therefore interpreted with caution. Nevertheless, the SNPs identified in the ELN gene showed a significant statistical association with the degree of ligament injuries $(\mathrm{p}=0.009)$ and with recovery time ( $\mathrm{p}=0.043)$. ELN, a self-assembling extracellular matrix protein, is the major source of tissue elasticity
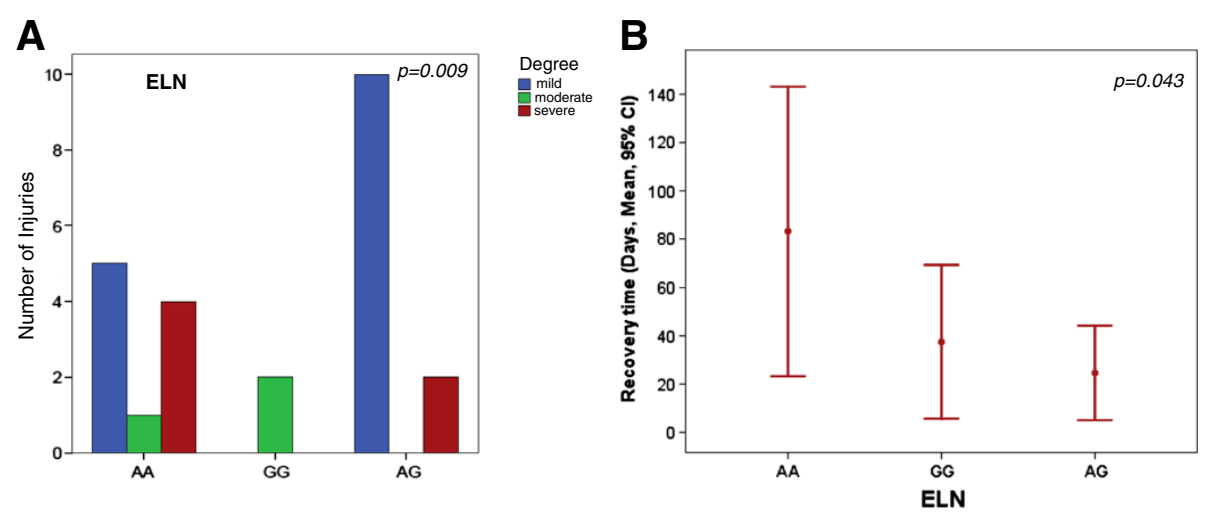

Figure 2 ELN related to ligament injuries. Relation of ELN with degree of injury and recovery time. A) Individuals without the G allele suffered more severe injuries (see Table 3). B) Carriers of the $G$ allele exhibited had faster recovery times. 
[57]. Individuals with the ELN AA genotype suffered more severe injuries and longer recovery times than those with the AG or the GG genotypes (Table 3). A previous study evaluating the relationship of the ELN SNP with age and arterial compliance in 320 individuals with no symptoms of cardiovascular disease and who had not received medications found that carriers of the A allele had decreased arterial compliance compared to those with the homozygous GG variant [58]. The shorter recovery time observed in the present study for carriers of the $G$ allele may be related to a more efficient elastin function, since altered elastin affects elastogenesis and the function of elastic fibers in vivo [23].

\section{Conclusions}

The genetic profile based on the study of SNPs constitutes a novel field of investigation in sports medicine and may help to identify individuals with a shorter recovery time and greater response to treatment and those at a greater risk of injury [29]. Since the study of genetic profiles in sports medicine is still in its early stages, further studies with larger samples are warranted to validate our findings.

\section{Additional file}

Additional file 1: $p$ values for the non-significant SNPs analyzed for each injury related to degree.

\section{Competing interests}

The authors declare that they have no competing interests.

\section{Authors' contributions}

RA and RP designed the study, interpreted the results and wrote the manuscript. JR and FC analyzed and interpreted the data and wrote the manuscript. BM performed the statistical analyses. CM was responsible for technical aspects of the study. GR helped interpret the results. NM helped in designing the study, interpreting the results, and finalizing the manuscript. All authors read and approved the final manuscript.

\section{Acknowledgements}

This work was awarded with the Premio Nacional de Medicina Deportiva de la Universidad de Oviedo. This study was funded by a Grant from Consejo Superior de Deportes (035/UPB10/12) and in part by a Grant from the UEFA Research Grant Programme Application (2012) and a. The authors thank Dr Mariano Monzo, chair of the Unit of Human Anatomy and Embryology, University of Barcelona School of Medicine for his constant support, Dr. Jordi Marcos and Dr. Javier Yanguas for providing some of the samples used in the study, and Aureli Altimira for providing data on work load.

\section{Author details}

${ }^{1}$ FC Barcelona Medical Services, Barcelona, Spain. ${ }^{2}$ Human Anatomy and Embryology Unit-School of Medicine-UB, Barcelona, Spain. ${ }^{3}$ School of Sports Medicine-School of Medicine-UB, Barcelona, Spain. ${ }^{4}$ Department of Pharmacy and Pharmaceutical Technology-School of Pharmacy-UB, Barcelona, Spain. ${ }^{5}$ Department of Health and Applied Science-INEFC-UB, Barcelona, Spain. ${ }^{6} \mathrm{FC}$ Barcelona Department of Physics Preparation, Barcelona, Spain. ${ }^{7}$ Centre for Sports and Exercise Medicine, Queen Mary University of London, Barts and The London School of Medicine and Dentistry, London, UK.

Received: 12 June 2013 Accepted: 3 July 2013

Published: 26 July 2013

\section{References}

1. Meeuwisse WH: Assessing causation in sport injury: a multifactorial model. Clin J Sport Med 1994, 4:166-170.

2. Collins M: Genetic risk factors for soft-tissue injuries 101: a practical summary to help clinicians understand the role of genetics and 'personalised medicine'. Br J Sports Med 2010, 44:915-917.

3. Riley G: The pathogenesis of tendinopathy. A molecular perspective. Rheumatology 2004, 43:131-142.

4. Maffulli N, Wong J, Almekinders LC: Types and epidemiology of tendinopathy. Clin Sports Med 2003, 22:675-692.

5. Ekstrand J, Hägglund $M$, Waldén M: Epidemiology of muscle injuries in professional football (soccer). Am J Sports Med 2011, 39:1226-1232.

6. Ekstrand J, Hägglund $M$, Waldén $M$ : Injury incidence and injury patterns in professional football: the UEFA injury study. Br I Sports Med 2011, 45:553-558.

7. Ekstrand J, Healy JC, Waldén M, Lee JC, English B, et al: Hamstring muscle injuries in professional football: the correlation of MRI findings with return to play. Br J Sports Med 2012, 46:112-117.

8. Ekstrand J, Timpka T, Hägglund M: Risk of injury in elite football played on artificial turf versus natural grass: a prospective two-cohort study. Br J Sports Med 2006, 40:975-980.

9. Hess GW: Ankle impingement syndromes: a review of etiology and related implications. Foot Ankle Spec 2011, 4:290-297.

10. Magra M, Maffulli N: Genetic aspects of tendinopathy. J Sci Med Sport 2008, 11:243-247.

11. Longo U, Fazio V, Poeta M, Rabitti C, Franceschi F, et al: Bilateral consecutive rupture of the quadriceps tendon in a man with BstUI polymorphism of the COL5A1 gene. Knee Surg Sports Traumatol ArthrosC 2010, 18:514-518.

12. Laguette $M-J$, Abrahams $Y$, Prince $S$, Collins M: Sequence variants within the $3^{\prime}-$ UTR of the COL5A1 gene alters mRNA stability: implications for musculoskeletal soft tissue injuries. Matrix Biol 2011, 30:338-345.

13. Lippi G, Longo UG, Maffulli N: Genetics and sports. Br Med Bull 2010, 93:27-47.

14. Cupeiro R, Benito PJ, Maffulli N, Calderón FJ, González-Lamuño D: MCT1 genetic polymorphism influence in high intensity circuit training: a pilot study. J Sci Med Sport 2010, 13:526-530.

15. Harmon BT, Orkunoglu-Suer EF, Adham K, Larkin JS, Gordish-Dressman H, et al: CCL2 and CCR2 variants are associated with skeletal muscle strength and change in strength with resistance training. J Appl Physiol 2010, 109(6):1779-1785.

16. Magra M, Maffulli N: Genetics: does it play a role in tendinopathy? Clin J Sport Med 2007, 17:231-233.

17. Mokone GG, Gajjar M, September AV, Schwellnus MP, Greenberg J, et al: The guanine-thymine dinucleotide repeat polymorphism within the tenascin- $\mathrm{C}$ gene is associated with achilles tendon injuries. Am J Sports Med 2005, 33:1016-1021.

18. September AV, Schwellnus MP, Collins M: Tendon and ligament injuries: the genetic component. Br J Sports Med 2007, 41:241-246.

19. Posthumus $M$, September AV, O'Cuinneagain D, van der Merwe $W$, Schwellnus MP, et al: The COL5A1 gene is associated with increased risk of anterior cruciate ligament ruptures in female participants. Am J Sports Med 2009, 37:2234-2240.

20. Yamin C, Duarte J, Oliveira J, Amir O, Sagiv M, et al: IL6 (-174) and TNFA $(-308)$ promoter polymorphisms are associated with systemic creatine kinase response to eccentric exercise. Eur J Appl Physiol 2008, 104:579-586.

21. Paulin D, Huet A, Khanamyrian L, Xue Z: Desminopathies in muscle disease. J Pathol 2004, 204:418-427.

22. Rosenbloom J: Elastin: relation of protein and gene structure to disease. Lab Invest 1984, 51:605.

23. Sherratt M: Tissue elasticity and the ageing elastic fibre. Age 2009, 31:305-325.

24. Itoh-Satoh M, Hayashi T, Nishi H, Koga Y, Arimura T, et al: Titin mutations as the molecular basis for dilated cardiomyopathy. Biochem Biophys Res Commun 2002, 291:385-393.

25. Lee HJ, Goring W, Ochs M, Muhlfeld C, Steding G, et al: Sox15 is required for skeletal muscle regeneration. Mol Cell Biol 2004, 24:8428.

26. Devaney JM, Hoffman EP, Gordish-Dressman H, Kearns A, Zambraski E, et al: IGF-II gene region polymorphisms related to exertional muscle damage. J Appl Physiol 2007, 102:1815-1823. 
27. Hubal MJ, Devaney JM, Hoffman EP, Zambraski EJ, Gordish-Dressman H, et al: CCL2 and CCR2 polymorphisms are associated with markers of exerciseinduced skeletal muscle damage. J Appl Physiol 2010, 108:1651-1658.

28. Collins M, Raleigh SM: Genetic risk factors for musculoskeletal soft tissue injuries. Med Sport Sci 2009, 54:49.

29. Kambouris M, Ntalouka F, Ziogas G, Maffulli N: Predictive genomics DNA profiling for athletic performance. Recent Pat DNA Gene Seq 2012, 6:229-239.

30. Hägglund $M$, Waldén $M, B a h r R$, Ekstrand J: Methods for epidemiological study of injuries to professional football players: developing the UEFA model. Br J Sports Med 2005, 39:340-346.

31. Chan O, Del Buono A, Best TM, Maffulli N: Acute muscle strain injuries: a proposed new classification system. Knee Surg Sports Traumatol ArthrosC 2012, 20(11):2356-2362.

32. Pruna R, Medina D, Rodas G, Artells R: Patellar tendinopathy. Therapeutic model in the sport. Med Clin (Barc) 2013. doi:10.1016/j.medcli.2012.12.006.

33. Gil Rodas RP, Lluis T, Carles M: Guia de práctica Clinica de las lesiones musculares. Epidemiologia, diagnóstico, tratamiento y prevención. APUNTS MEDICINA DE L'ESPORT 2009, 44:179-203.

34. Schwellnus MP: Genetics and soft-tissue injuries in sport: clinical commentary. Curr Sports Med Rep 2011, 10:126-127. 110.1249/JSR.1240b 1013e31821ac31820eb.

35. Fuller CW, Hawkins RD: Assessment of football grounds for player safety. Safety Science 1997, 27:115-128.

36. Fuller CW, Junge A, Dvorak J: Risk management: FIFA's approach for protecting the health of football players. Br J Sports Med 2012, 46:11-17.

37. Sport U Staging major sports events: The guide. London: UK Sport; 2005.

38. Maughan R, Shirreffs S, Ozgünen K, Kurdak S, Ersöz G, et al: Living, training and playing in the heat: challenges to the football player and strategies for coping with environmental extremes. Scand J Med Sci Sports 2010, 20:117-124.

39. Levine B, Stray-Gundersen J, Mehta R: Effect of altitude on football performance. Scand J Med Sci Sports 2008, 18:76-84.

40. Hawkins RD, Fuller CW: A prospective epidemiological study of injuries in four English professional football clubs. Br J Sports Med 1999, 33:196-203.

41. Peterson L, Junge A, Chomiak J, Graf-Baumann T, Dvorak J: Incidence of football injuries and complaints in different age groups and skill-level groups. Am J Sports Med 2000, 28:S-51-S-57.

42. Schmidt-Olsen S, Jørgensen U, Kaalund S, Sørensen J: Injuries among young soccer players. Am J Sports Med 1991, 19:273-275.

43. Fuller CW, Dick RW, Corlette J, Schmalz R: Comparison of the incidence, nature and cause of injuries sustained on grass and new generation artificial turf by male and female football players. Part 1: match injuries. Br J Sports Med 2007, 41:i20-i26.

44. Fuller CW, Dick RW, Corlette J, Schmalz R: Comparison of the incidence, nature and cause of injuries sustained on grass and new generation artificial turf by male and female football players. Part 2: training injuries. Br J Sports Med 2007, 41:i27-i32.

45. Dvorak J, Junge A, Chomiak J, Graf-Baumann T, Peterson L, et al: Risk factor analysis for injuries in football players. Am J Sports Med 2000, 28:S-69-S-74.

46. Falvo MJ, Bloomer RJ: Review of exercise-induced muscle injury: relevance for athletic populations. Res Sports Med 2006, 14:65-82.

47. Ahmad I, Narang R, Venkatraman A, Das N: Frequency distribution of the single-nucleotide $-108 \mathrm{C} / \mathrm{T}$ polymorphism at the promoter region of the PON1 gene in Asian Indians and its relationship with coronary artery disease. J Community Genet 2011, 2:27-32.

48. Zeng W, Liu L, Tong Y, Liu H, Dai L, et al: A66G and C524T polymorphisms of the methionine synthase reductase gene are associated with congenital heart defects in the Chinese Han population. Genet Mol Res 2011, 10:2597-2605.

49. Ekstrand J, Gillquist J: Soccer injuries and their mechanisms: a prospective study. Med Sci Sports Exerc 1983, 15:267-270.

50. Adams GR: Invited review: autocrine/paracrine IGF-I and skeletal muscle adaptation. J Appl Physio/ 2002, 93:1159-1167.

51. Goldspink $G$, Williams $P$, Simpson $H$ : Gene expression in response to muscle stretch. Clin Orthop Relat Res 2002, 403:S146.

52. Keller HL, St Pierre Schneider B, Eppihimer LA, Cannon JG: Association of IGF-I and IGF-II with myofiber regeneration in vivo. Muscle Nerve 1999, 22:347-354.

53. Yahiaoui L, Gvozdic D, Danialou G, Mack M, Petrof BJ: CC family chemokines directly regulate myoblast responses to skeletal muscle injury. J Physiol 2008, 586:3991-4004.
54. Kadler KE, Baldock C, Bella J, Boot-Handford RP: Collagens at a glance. J Cell Sci 2007, 120:1955-1958.

55. Collins M: Posthumus M Type V Collagen Genotype and Exercise-Related Phenotype Relationships: A Novel Hypothesis. Exerc Sport Sci Rev 2011, 39:191.

56. Brown JC, Miller CJ, Posthumus M, Schwellnus MP, Collins M: The COL5A1 gene, ultra-marathon running performance, and range of motion. Int J Sports Physiol Perform 2011, 6(4):485-496.

57. Muiznieks LDMLD, Weiss ASWAS, Keeley FWKFW: Structural disorder and dynamics of elastin. Biochem Cell Biol 2010, 88:239-250. This paper is one of a selection of papers published in this special issue entitled "Canadian Society of Biochemistry, Molecular \& Cellular Biology. 52nd Annual MeetingProtein Folding: Principles and Diseases" and has undergone the Journal's usual peer review process.

58. Hanon O, Luong V, Mourad JJ, Bortolotto LA, Jeunemaitre $X$, et al: Aging, carotid artery distensibility, and the Ser422Gly elastin gene polymorphism in humans. Hypertension 2001, 38:1185-1189.

doi:10.1186/1471-2474-14-221

Cite this article as: Pruna et al:: Single nucleotide polymorphisms associated with non-contact soft tissue injuries in elite professional soccer players: influence on degree of injury and recovery time. BMC Musculoskeletal Disorders 2013 14:221.

\section{Submit your next manuscript to BioMed Central and take full advantage of:}

- Convenient online submission

- Thorough peer review

- No space constraints or color figure charges

- Immediate publication on acceptance

- Inclusion in PubMed, CAS, Scopus and Google Scholar

- Research which is freely available for redistribution 